\title{
Extrasynaptic $\alpha 7-$ Nicotinic Acetylcholine Receptor Expression in Developing Neurons Is Regulated by Inputs, Targets, and Activity
}

\author{
Craig L. Brumwell, James L. Johnson, and Michele H. Jacob \\ Department of Neuroscience, Tufts University, Sackler School of Biomedical Sciences, Boston, Massachusetts 02111
}

$\alpha 7-$ Nicotinic acetylcholine receptors (nAChRs) are widely expressed in the vertebrate nervous system. $\alpha 7-\mathrm{nAChR}$ functions include postsynaptic transmission, modulating neurotransmitter release, reinforcing nicotine addiction, and a role in neurological disorders, such as schizophrenia and Alzheimer's disease. In chick parasympathetic ciliary ganglion (CG) neurons, $\alpha 7-\mathrm{nAChRs}$ are excluded from the synapse and localize perisynaptically. Despite their extrasynaptic distribution, the highly $\mathrm{Ca}^{2+}$-permeable $\alpha 7-\mathrm{nAChRs}$ have important synapse-related $\mathrm{Ca}^{2+}$-dependent signaling functions in the $\mathrm{CG}$. We show here that the synaptic partners regulate $\alpha 7-\mathrm{nAChR}$ expression during synapse formation in embryonic CG neurons in situ. The absence of inputs and target tissues cause reductions in $\alpha 7$ -
nAChR mRNA and protein levels that primarily resemble those seen for synaptic $\alpha 3-n A C h R s$. However, there is a difference in their regulation. $\alpha 7-\mathrm{nAChR}$ levels are downregulated by reduced activity, whereas $\alpha 3-n A C h R$ levels are not. We propose that the activity-dependent regulation of extrasynaptic $\alpha 7$ nAChR levels may be an important mechanism for postsynaptic CG neurons to detect changes in presynaptic activity levels and respond with $\mathrm{Ca}^{2+}$-dependent plasticity changes in gene expression.

Key words: nicotinic acetylcholine receptor; nAChR; $\alpha 7 ; \alpha 3$; neuron-specific gene expression; synapse formation; innervation; target tissue interactions; induction; electrical activity; visual deprivation; ciliary ganglion; neuron
Synapses are essential for intercellular communication and rapid information processing in the nervous system. Given their central role in neural function, it is surprising that the mechanisms that regulate interneuronal synapse differentiation are still primarily undefined. Within a single neuron, multiple types of neurotransmitter receptors are active and targeted to discrete synaptic regions for proper function. The expression of receptors that concentrate at the postsynaptic membrane is regulated by both presynaptic inputs and retrograde signals from the target tissues (Levey et al., 1995; Broide et al., 1996; Levey and Jacob, 1996; Zhou et al., 1998, 2001; Devay et al., 1999). We define here the regulatory effects of synaptic partners on the expression of receptors that are excluded from the synapse and restricted to perisynaptic regions of the neuron surface membrane.

Nicotinic acetylcholine receptors (nAChRs) mediate fast excitatory synaptic transmission through the chick parasympathetic ciliary ganglion (CG). Chick CG neurons express two distinct types of nAChRs, $\alpha 3$-nAChRs and $\alpha 7$-nAChRs, that differ in their subunit composition and spatial distribution. $\alpha 3$-nAChRs, composed of $\alpha 3, \alpha 5$, and $\beta 4$ (occasionally $\beta 2$ ) subunits, are concentrated in the specialized postsynaptic membrane (Jacob et al., 1986; Loring and Zigmond, 1987; Vernallis et al., 1993). In

\footnotetext{
Received April 9, 2002; revised July 1, 2002; accepted July 10, 2002.
}

This work was supported by National Institutes of Health Grant 21725 (M.H.J.). We thank Marjory Levey for designing and testing the primers, Ogi Ikonomov for optimizing PCR conditions, Rachel Blitzblau and Brian Williams for generous help in preparing the figures, and Madelaine Rosenberg for insightful comments on this manuscript.

Correspondence should be addressed to Dr. Michele Jacob, Department of Neuroscience, Tufts University, Sackler School of Biomedical Sciences, 136 Harrison Avenue, Boston, MA 02111. E-mail: michele.jacob@tufts.edu.

C. L. Brumwell's present address: University of Massachusetts Medical Center, Department of Biochemistry and Molecular Pharmacology, Biotech 4, Worcester, MA 01605.

J. L. Johnson's present address: Department of Anesthesia, Tri-City Medical Center, 4002 Vista Way, Oceanside, CA 92056.

Copyright (C) 2002 Society for Neuroscience $0270-6474 / 02 / 228101-09 \$ 15.00 / 0$ contrast, $\alpha 7$-nAChRs, composed of $\alpha 7$ subunits, are excluded from the synapse at all ages ranging from early embryonic to reproductively mature adult CGs (Jacob and Berg, 1983; Loring et al., 1985; Vernallis et al., 1993; Conroy and Berg, 1995; Horch and Sargent, 1995; Shoop et al., 1999). The $\alpha 7-n A C h R s$ are restricted to perisynaptic regions in which they accumulate on the surface membrane of short dendrites that emerge from the postsynaptic neuron in the region of innervation. Presynaptically released acetylcholine activates both nAChR types, but their functional properties differ. Compared with $\alpha 3$-nAChRs, the $\alpha 7$-nAChRs have higher calcium permeability and faster activation and desensitization kinetics (Ullian et al., 1997; Chang and Berg, 1999). The different properties and spatial segregation of the two receptor types are likely to create functionally specialized synapse-associated microregions. Perisynaptic $\alpha 7-\mathrm{nAChR}$ activation is required for reliable synaptic transmission and synchronous firing at early embryonic ages (Chang and Berg, 1999). However, during synapse maturation at older embryonic ages, $\alpha 7$-nAChRs are not required for reliable synaptic transmission but have other synapse-related, $\mathrm{Ca}^{2+}$-dependent functions in $\mathrm{CG}$ neurons. Specifically, extrasynaptic $\alpha 7-n A C h R s$ mediate process remodeling, neuron survival, and $\mathrm{Ca}^{2+}$-dependent synaptically regulated changes in gene expression (Pugh and Berg, 1994; Pugh and Margiotta, 2000; Chang and Berg, 2001).

We report here the first in vivo analysis of the role of innervation and target tissues in regulating $\alpha 7$-nAChR expression during interneuronal synapse formation. We show that synaptic partners regulate the developmental expression of receptors that are excluded from the synapse. The absence of innervation and target tissues produce changes in extrasynaptic $\alpha 7$-nAChR subunit mRNA and protein levels that primarily parallel those seen for synaptic $\alpha 3$-nAChR subunits in embryonic chick CG neurons (Levey at al., 1995). However, there is a difference in the regulation of the two nicotinic receptor types. $\alpha 7-\mathrm{nAChR}$ levels are 
downregulated by visual deprivation-reduced activity, whereas $\alpha 3$-nAChR levels are not. Our findings suggest that $\alpha 7$-nAChRs have a unique synapse-related function as activity sensors in postsynaptic CG neurons.

\section{MATERIALS AND METHODS}

Chick embryos, staging, and surgical manipulations. White Leghorn embryonated chick eggs (Spafas, Norwich, CT) were maintained at $37^{\circ} \mathrm{C}$ in a forced-draft turning incubator until use. Embryos were staged according to the classification scheme of Hamburger and Hamilton (1951). Surgical micromanipulations to prevent preganglionic innervation or postganglionic target tissue interactions were performed as described in detail previously (Arenella et al., 1993; Dourado et al., 1994). Briefly, the sole source of presynaptic input, the accessory oculomotor nucleus, was ablated bilaterally at embryonic day 3.5 (E3.5) to E4, or the developing optic vesicle, which contains the target muscles, was unilaterally removed at E2. The surgeries are timed to precede synaptogenesis. To obtain ganglia deprived of both innervation and target tissues, the developing eye was removed at E2 and the preganglionic nucleus at E3.5-E4 in the same embryo (Levey et al., 1995). To ensure the complete removal of preganglionic and postganglionic tissues, ganglia were only dissected from embryos lacking visible preganglionic connections to the CG and residual eye structures. The complete removal of all preganglionic neurons and the absence of aberrant innervation from other sources or intraganglionic contacts were established by paraffin histological examination of the brain of operated embryos, by immunocytochemical labeling with monoclonal antibodies (mAbs) to synaptic vesicle antigens, and by ultrastructural analysis (Engisch and Fischbach, 1992; Arenella et al., 1993). CGs from normal-developing, operated and sham-operated embryos were dissected at selected stages of synapse formation and maturation, ranging from E5 to E15. CGs were immediately frozen in liquid nitrogen and stored at $-80^{\circ} \mathrm{C}$ until use for reverse transcription (RT)PCR or were fixed and processed for histochemical staining.

Quantitative RT-PCR. Quantitative RT-PCR was performed as described previously, with the following modifications to optimize amplification of $\alpha 7$ mRNA in individual CGs (Levey et al., 1995; Levey and Jacob, 1996). Briefly, total RNA was extracted from individual ganglia by the guanidinium isothiocyanate-hot phenol method (Feramisco et al., 1982 ) as modified by the addition of glycogen as carrier. Known concentrations of an $\alpha 7$-nAChR mutated cRNA internal standard, equivalent to the quantity of that transcript present in that age operated or control ganglion (as determined initially by competitive RT-PCR), were added to the ganglion at the start of RNA extraction. The use of serial dilutions of internal standard in competitive PCR demonstrated that PCR amplification of $\alpha 7$ is linear over the concentration range of $\alpha 7$ transcripts in operated and control CGs. $\alpha 7$ mutated standard was generated by sitedirected mutagenesis with PCR (Higuchi et al., 1988) and resembles the region of the cellular $\alpha 7$ mRNA targeted for amplification with the exception of two base pair changes [at nucleotides (nt) 1170 and 1172] required to replace an existing TaqI restriction endonuclease site with a novel $X b a$ I site. Mutated $\alpha 7$ product was subcloned in pCR vector (Invitrogen, San Diego, CA) and sequence verified (Sequenase version 2.0; Stratagene, La Jolla, CA). cRNA was generated by in vitro transcription (MEGA short script; Ambion, Austin, TX), and the concentrations were determined by $\mathrm{OD}_{260}$ measurements. Ganglionic RNA and the mutated $\alpha 7$ internal standard cRNA were amplified by quantitative RT-PCR in the presence of [ $\alpha^{32}$-P]dCTP using $\alpha 7$-specific primers. The $\alpha 7$ sense and antisense primers correspond to regions in exons 9 and 10 and flank the cytoplasmic domain between transmembrane regions III and IV (Couturier et al., 1990). The sequence of the forward primer is 5' TGATTATTGTTGGCCTCTCTG (nt 906-926). The reverse primer is 5' TGGTGCTGACATTAAGATGCC (nt 1457-1477). Briefly, singlestranded cDNA was synthesized by Moloney murine leukemia virus reverse transcriptase (MMLV-RT) (Promega, Madison, WI) and specific priming with the $\alpha 7$ reverse primer. The $20 \mu$ l reaction contained RNA from one CG, $10 \mu \mathrm{M}$ antisense primer, $250 \mu \mathrm{M}$ each dNTP, $0.5 \mathrm{U}$ of RNasin (Promega), $0.1 \mathrm{M}$ dithiothreitol, $20 \mathrm{U}$ of MMLV-RT, and buffer. The RNA and the antisense primer were heat denatured and then reverse transcribed for $1 \mathrm{hr}$ at $42^{\circ} \mathrm{C}$. Single-stranded cDNA was amplified by PCR in a programmable thermocycler (MJ Research, Watertown, MA) in a final volume of $20 \mu$ l. First, enzyme buffer, $\mathrm{dH}_{2} 0$, dNTPs, 1.5 $\mathrm{mM} \mathrm{MgCl}_{2}, 10 \mu \mathrm{M}$ sense primer, and Ampliwax to reduce nonspecific priming (Stratagene) were heated at $80^{\circ} \mathrm{C}$ for $5 \mathrm{~min}$ and then allowed to cool. To the top of the wax layer, we added buffer, 1.0 U of TaqDNA polymerase (Promega), $10 \mathrm{nCi}$ of $\left[\alpha^{32}-\mathrm{P}\right] \mathrm{dCTP}$ (DuPont NEN, Boston, $\mathrm{MA})$, and $2 \mu \mathrm{l}$ of the RT product. The samples were heat denatured at $94^{\circ} \mathrm{C}$ for $2 \mathrm{~min}$, amplified ( 30 cycles: denaturation at $94^{\circ} \mathrm{C}$ for $40 \mathrm{sec}$, primer annealing at $63^{\circ} \mathrm{C}$ for $1 \mathrm{~min}$, and DNA extension at $72^{\circ} \mathrm{C}$ for 1.5 $\mathrm{min}$ ), and incubated for a final $10 \mathrm{~min}$ at $72^{\circ} \mathrm{C}$ to complete extension. For comparison with $\alpha 7, \alpha 3$ transcript levels and $\mathrm{c} \beta 4$-tubulin transcript levels, as a negative control, were also measured by quantitative RT-PCR with $\alpha 3$ and $\mathrm{c} \beta 4$-tubulin mutated internal standard cRNAs, respectively, and specific primers as reported previously (Levey et al., 1995; Levey and Jacob, 1996), but using Ampliwax and the higher annealing temperature detailed above. Restriction enzyme mapping and gel electrophoresis were used to distinguish PCR products derived from the mutated standards and the ganglionic mRNAs. Fragments were transferred to a Zeta probe blotting membrane (Bio-Rad, Hercules, CA) and exposed x-ray film. The ratio of the ganglionic mRNA products and the mutated standard products was determined by densitometric scanning (PDI densitometer; PDI, Huntington Station, NY) of the resulting autoradiogram.

Neuronal cell counts. Neuron numbers in normal developing ganglia were taken from Landmesser and Pilar (1974) and Furber et al. (1987). Neuron numbers in CGs from operated and sham-operated embryos at E8 and E12-E14 were determined as described previously (Levey et al., 1995). Briefly, ganglia were fixed, processed for paraffin histology, serially sectioned at $8 \mu \mathrm{m}$, and stained with toluidine blue (Arenella et al., 1993). All neurons possessing a nucleus with a distinct nucleolus were counted in each section of the ganglion. Cell counts were corrected for double counting by the method of Abercrombie (1946).

Histochemical staining procedures. $\alpha 7$-nAChR levels were examined in CG neurons of operated and control embryos by histochemical staining of frozen ganglion sections. CGs were dissected from normal, shamoperated and operated embryos at ages ranging from E5 to E18 (stages 25-44). Ganglia were lightly fixed with $0.25 \%$ paraformaldehyde in PBS under vacuum for $1 \mathrm{hr}$, embedded, and frozen sectioned as described previously (Jacob, 1991; Arenella et al., 1993). Sections (8- $\mu$ m-thick) of age-matched CGs from operated and control embryos were mounted on the same slide and processed in parallel for comparison of $\alpha 7-\mathrm{nAChR}$ staining. The sections were rinsed in PBS containing $0.75 \%$ glycine to reduce nonspecific staining, incubated with biotinylated $\alpha$-bungarotoxin $(\alpha$-Bgt) (Molecular Probes, Eugene, OR) at 1:100 or 1:200 dilution in PBS for $1 \mathrm{hr}$, rinsed in PBS with $0.5 \mathrm{M} \mathrm{NaCl}$, and incubated for $40 \mathrm{~min}$ with an avidin-biotinylated horseradish peroxidase (HRP) complex (Vectastain Elite ABC kit; Vector Laboratories, Burlingame, CA) that was prepared in PBS according to the instructions of the manufacturer. Alternatively, some sections were incubated with biotinylated $\alpha$-Bgt at 1:40 dilution and streptavidin-HRP conjugate (Vector Laboratories) at 1:20 dilution in PBS. The sections were then reacted for peroxidase activity and mounted as described previously (Jacob, 1991; Arenella et al., 1993) and viewed by bright-field microscopy with a Zeiss (Thornwood, NY) Axioskop microscope. To establish the specificity of $\alpha$-Bgt staining, a few slides from each experiment were processed as described above, except that biotinylated $\alpha$-Bgt was replaced with PBS.

For comparison with the $\alpha 7$-nAChR staining levels, alternate frozen ganglion sections from the operated, sham-operated and normal embryos were immunolabeled for three other neuron-specific components, synaptic vesicle protein SV2 and two microtubule-associated proteins, MAP1B and MAP2, as described previously (Arenella et al., 1993). The anti-SV2 mouse $\mathrm{mAb}$ to the synaptic vesicle transmembrane transporter (generously provided by Dr. Kathleen Buckley, Harvard Medical School, Boston, MA) was used at a 1:100 dilution in PBS. The anti-MAP1B-2 mouse $\mathrm{mAb}$ to MAP1B and the anti-MAP2 mouse mAb (the generous gift from Dr. Richard Vallee, Columbia University, New York, NY) were both used at a 1:200 dilution in PBS.

Visual deprivation. White Leghorn chicks were hatched in a darkened incubator in our laboratory, raised in complete darkness (dark reared) in temperature-controlled brooders, and force-fed as described previously (Gottlieb et al., 1987). All other newly hatched chicks were maintained on a $12 \mathrm{hr}$ light/dark cycle (diurnally reared). In one group of the diurnally reared chicks, we covered one eye with an opaque black plastic dome-like goggle (light-tight occluder) to prevent light entry and visual function. The occluder (kindly provided by Dr. Josh Wallman of City College of New York, New York, NY) was glued to the circumorbital feathers and skin surrounding the eye (Wallman et al., 1978; Gottlieb et al., 1987; Shih et al., 1993). The CG from the contralateral untreated eye served as an internal control. To control for nonspecific effects of covering the eye, a clear occluder was applied over one eye in separate chicks. 


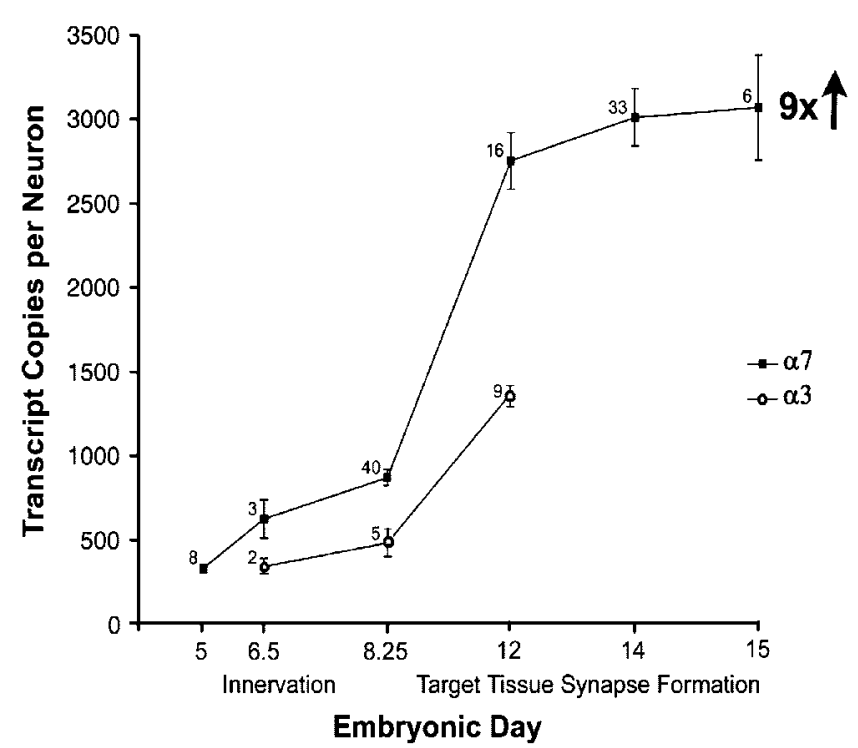

Figure 1. $\quad \alpha 7$ subunit transcript levels increase during preganglionic and postganglionic synapse formation and then plateau in embryonic CG neurons in situ. Absolute amounts of $\alpha 7$ subunit mRNAs were measured in individual ganglia at landmark stages of synaptogenesis by using quantitative RT-PCR with a mutated $\alpha 7$ cRNA internal standard. Values are normalized to the number of transcript copies per neuron to account for developmental changes in neuron number. Each value represents the mean \pm SEM of the number of separate determinations indicated for each time point. For comparison, synaptic $\alpha 3$ subunit mRNA levels were measured at three key stages of preganglionic and postganglionic synapse formation. $\alpha 7$ transcript levels increase ninefold from E5 to E15 and are twofold greater than $\alpha 3$ mRNA levels at all stages of synaptogenesis examined.

Treatments started at hatching and lasted for 1 or 2 weeks. In all conditions, food and water were available ad libitum.

$n A C h R$ assays. The total number of $\alpha 7$-nAChRs (surface plus internal) in CGs from visually deprived and control newly hatched chicks was determined. A filter assay was used to measure specific binding of ${ }^{125} \mathrm{I}-\alpha$-Bgt to CG detergent extracts as described previously (Jacob and Berg, 1987). For comparison with $\alpha 7$-nAChRs, $\alpha 3$-nAChR levels were measured using ${ }^{125} \mathrm{I}-\mathrm{mAb}-35$ binding to $\mathrm{CG}$ detergent extracts and separation of the bound ${ }^{125} \mathrm{I}-\mathrm{mAb}-35$ by ion exchange chromatography on DEAE-cellulose (Jacob and Berg, 1987). Specific binding was calculated as the difference between total binding and nonspecific binding, in which nonspecific binding was determined by including a 40 -fold excess of cold ligand in the binding reaction. The amount of specific binding per ganglion was normalized for the relative amount of total protein. Total ganglionic protein was measured in detergent extracts by the microtiter protein assay (Bio-Rad) as performed according to the instructions of the manufacturer.

\section{RESULTS}

\section{$\alpha 7$ subunit mRNA levels increase dramatically during synaptogenesis}

$\alpha 7$ transcript levels in individual chick CGs were established at landmark stages of synapse formation and maturation, ranging from E5 to E15 (Fig. 1). Innervation precedes target tissue synapse formation in the CG. Innervation begins at E4.5, and, by E8, functional chemical synapses are present on every neuron (Landmesser and Pilar, 1972; Jacob, 1991). From E8.5 to E14, CG neurons establish functional connections with their target cells, striated and smooth muscles in the eye (Meriney and Pilar, 1987; Pilar et al., 1987).

The absolute levels of $\alpha 7$ mRNA per ganglion were measured using quantitative RT-PCR and known concentrations of a mutated $\alpha 7$ cRNA internal standard. The internal standard differed from the targeted $\alpha 7$ sequence by two base pair changes introduced to create a novel restriction enzyme site $(X b a \mathrm{I})$ and remove an existing site (TaqI). $\alpha 7$ transcript levels were normalized to account for declines in CG neuron number attributable to naturally occurring cell death from E9 to E14, with greater declines occurring in CGs surgically deprived of synaptic interactions (see below) (Landmesser and Pilar, 1974; Furber et al., 1987; Levey et al., 1995).

$\alpha 7$ subunit mRNA levels per CG neuron increase ninefold during preganglionic and postganglionic synapse formation in situ, from E5 to E15 (Fig. 1). The greatest rise occurs between E8.25 and E12, during the time of target tissue innervation and maturational changes in the efficacy and morphology of preganglionic inputs, with calyces forming on the ciliary neurons (Landmesser and Pilar, 1972). Similar to the developmental increases in extrasynaptic $\alpha 7$ subunit mRNA, synaptic $\alpha 3, \beta 4$, and $\alpha 5$ subunit transcript levels per CG neuron rise 7-, 5-, and 16-fold, respectively, over the same time course, from E4 to E15 (Fig. 1) (Corriveau and Berg, 1993; Levey and Jacob, 1996). $\alpha 7$ mRNA levels are twofold more abundant than $\alpha 3$ transcripts at all of the stages of synapse formation examined (Fig. 1). A similar difference between $\alpha 7$ and $\alpha 3$ mRNA levels in embryonic CG neurons was observed by quantitative RNase protection assays (Corriveau and Berg, 1993). The temporal correlation of the increases in $\alpha 7$ subunit mRNA levels with preganglionic and postganglionic synapse formation suggests that innervation and target tissues may induce the rise.

\section{$\alpha 7$ transcript levels are lower in the absence of synaptic partners}

To determine the respective roles of innervation and target tissues in inducing the developmental increases in $\alpha 7$, we measured $\alpha 7$ subunit mRNA levels in CG neurons surgically deprived of these synaptic partners in situ. To prevent innervation, we bilaterally ablated the sole source of presynaptic inputs, the accessory oculomotor nucleus in the midbrain. To prevent target tissue interactions, we unilaterally removed the developing optic vesicle, with the contralateral ganglion serving as an internal control (Levey et al., 1995). Surgeries were performed before synaptogenesis and cause no direct damage to $\mathrm{CG}$ neurons or transection of their processes. Neuron numbers are reduced because of the removal of sources of trophic support (data not shown) (Landmesser and Pilar, 1974; Furber et al., 1987; Levey et al., 1995). Importantly, a stable population of neurons is retained in all operated conditions. These neurons are healthy based on ultrastructural and electrophysiological criteria and the demonstration of normal levels of specific mRNAs and proteins (Engisch and Fischbach 1990, 1992; Arenella et al., 1993; Dourado et al., 1994; Levey et al., 1995; Ikonomov et al., 1998). Input-deprived CG neurons form synapses on their target tissues, whereas innervation is established and maintained on target-deprived neurons (Landmesser and Pilar, 1974; Furber et al., 1987).

$\alpha 7$ subunit mRNA levels are decreased in CG neurons that have developed in the absence compared with the presence of synaptic partners in situ (Fig. 2, Table 1). In presynaptic inputdeprived neurons, the number of $\alpha 7$ transcript copies is reduced to 70 and $80 \%$ of sham-operated control neuron values at E8 and E12-E14, respectively. Compared with input deprivation, there are greater decreases in $\alpha 7 \mathrm{mRNA}$ levels in CG neurons that developed in the absence of the target tissues. Specifically, in target-deprived neurons, $\alpha 7$ transcript levels are $50 \%$ of contralateral control neuron values at both E8 and E12-E14. E8 


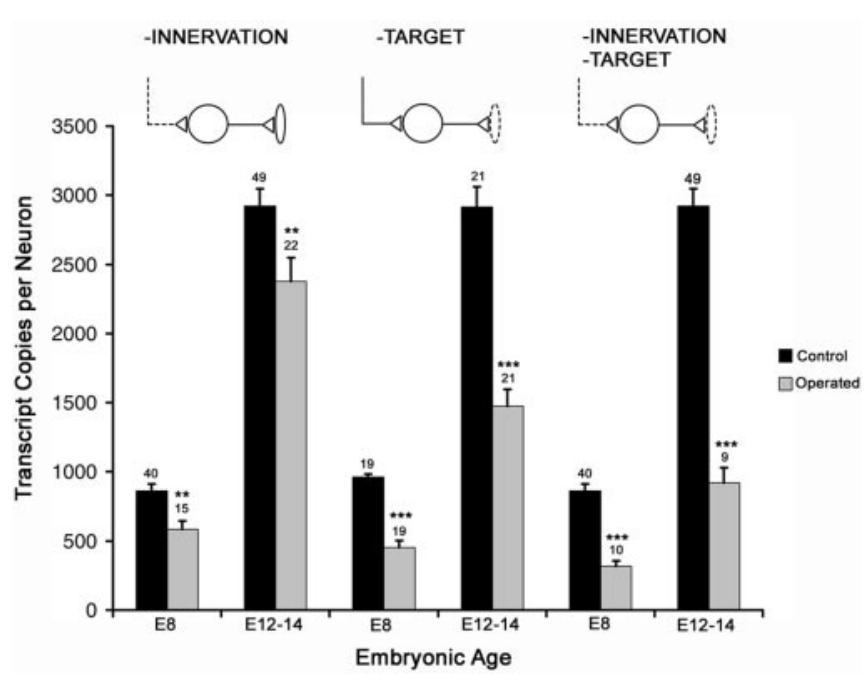

Figure 2. $\alpha 7$ transcript levels are reduced in CG neurons that have developed in the absence versus the presence of innervation, target tissues, or both synaptic partners. The absolute amounts of $\alpha 7$ subunit mRNA were determined in individual ganglia from operated (gray) and control (black) embryos at E8 and E12-E14 using quantitative RT-PCR. The values are expressed as the number of transcript copies per neuron to normalize for changes in neuron number after the surgeries. Results represent the mean \pm SEM. The number of ganglia assayed is shown above each bar. Ganglia deprived of inputs and both inputs and targets are compared with age-matched, sham-operated ganglia, whereas ganglia deprived of targets are compared with their contralateral control ganglia. Asterisks indicate statistically significant differences based on the Student's two-sided $t$ test; ${ }^{* *} p<0.01 ;{ }^{* *} p<0.001$.

\begin{tabular}{|c|c|c|c|c|c|}
\hline & & $\alpha 7$ & $\alpha 3$ & $\beta 4$ & $\alpha 5$ \\
\hline \multirow[t]{2}{*}{$\begin{array}{l}\text { Presynaptic } \\
\text { input-deprived }\end{array}$} & E8 & $1.4 x$ & $1.6 x$ & $1.6 x$ & $1.6 x$ \\
\hline & E12-14 & $1.3 x$ & -- & -- & $1.8 x$ \\
\hline \multirow[t]{2}{*}{ Target tissue-deprived } & E8 & $2 x$ & $2 x$ & $1.4 x$ & -- \\
\hline & E12-14 & $2 x$ & $2 x$ & $1.3 x$ & -- \\
\hline \multirow[t]{2}{*}{$\begin{array}{l}\text { Both input- and target } \\
\text { tissue-deprived }\end{array}$} & E8 & $3 x$ & $4 x$ & $4 x$ & $1.6 x$ \\
\hline & E12-14 & $3.3 x$ & $5.5 x$ & $6 x$ & $1.6 \mathrm{x}$ \\
\hline
\end{tabular}

Comparison of the decreases in extrasynaptic $\alpha 7$ subunit mRNA levels relative to those seen for synaptic $\alpha 3, \beta 4$, and $\alpha 5$ subunit mRNAs in CG neurons deprived of input, targets, and both synaptic partners. Data are expressed as the fold change in the absolute levels of nAChR subunit mRNA per neuron in the test condition relative to controls. For input-deprived CGs and both input- and target-deprived CGs, the sham-operated age-matched CGs are used as controls, whereas targetdeprived CGs are compared with the contralateral control CG from the same embryo. The $\alpha 7$ mRNA data are from Figure 2, and the $\alpha 3, \beta 4$, and $\alpha 5$ mRNA values are from Levey et al. (1995). - - Not significantly different from control values; Student's $t$ test.

precedes the time of peripheral synapse formation, but axons from CG neurons are already in the vicinity of the developing target tissues (Meriney and Pilar, 1987; Pilar et al., 1987). Thus, the decrease in $\alpha 7$ transcripts in E8 target-deprived neurons suggests that soluble factors from the target muscles retrogradely influence $\alpha 7$ transcript levels before synaptic contact. Overall, both inputs and target tissues regulate $\alpha 7$ mRNA levels during synapse formation and maturation in CG neurons.

To test for additive effects, both innervation and target tissue interactions were prevented from forming in single embryos. $\alpha 7$ transcript levels per neuron are lowest in CGs from these doubleoperated embryos, being decreased to $30-35 \%$ of control neuron values at both E8 and E12-E14 (Fig. 2, Table 1). Input and target tissue interactions have additive effects because $\alpha 7$ mRNA levels are significantly lower in CGs from double-operated embryos compared with the levels in CGs deprived of input alone and target alone (for input-deprived CGs, $p<0.005$ for E8 and $p<$ 0.001 for E12-E13; for target-deprived CGs, $p<0.05$ for E8 and $p<0.01$ for E12-E13; Student's $t$ test). In the absence of both synaptic partners, $\alpha 7$ transcript levels remain low relative to control values but increase threefold over time in situ, from E8 to E14 (Fig. 2), indicating that other regulatory influences, in addition to inputs and target tissues, induce $\alpha 7$ expression. As independent confirmation of the quantitative RT-PCR results, Northern blot analyses show similar declines in $\alpha 7$ mRNA levels for all operated conditions when the data are normalized per neuron number (data not shown).

The declines in $\alpha 7$ transcript levels in the absence of inputs and target tissues are specific. mRNA levels for $\mathrm{c} \beta 4$-tubulin, a neuronspecific form of $\beta$-tubulin (Sullivan et al., 1986; Lee et al., 1990), are not altered over the same time course in CGs from operated embryos, resembling our previous findings for $\mathrm{c} \beta 4$-tubulin (data not shown) (Levey et al., 1995; Ikonomov et al., 1998).

These regulatory changes in extrasynaptic $\alpha 7$ subunit transcript levels closely resemble the declines in synaptic $\alpha 3$-nAChR subunit mRNA levels in CGs from operated embryos (Levey et al., 1995). Transcripts encoding subunits of the extrasynaptic nAChRs and synaptic nAChRs, $\alpha 7$, and $\alpha 3, \beta 4$, and $\alpha 5$, respectively, are reduced to a similar extent, 1.4- to 2-fold, in the absence of inputs and targets. The only exception is that $\alpha 5$ mRNA levels are not significantly altered in target-deprived embryonic CG neurons but are decreased by input deprivation (Table 1) (Levey et al., 1995). Thus, the developmental expression of extrasynaptic $\alpha 7-n A C h R$ and synaptic $\alpha 3$-nAChR subunit mRNAs is primarily regulated in parallel by synaptic interactions.

Altogether, the data demonstrate that innervation and target tissues induce increases in perisynaptic $\alpha 7$ subunit mRNA levels during synapse formation in embryonic chick CG neurons in situ. Retrograde signals from the target tissues have the greater regulatory effects. The additive effects of removing both inputs and targets suggest that the two different synaptic partners provide distinct regulatory signals.

\section{$\alpha 7-n A C h R$ protein levels are reduced in the absence of synaptic partners}

For comparison with $\alpha 7$ transcripts, we examined the regulatory changes in $\alpha 7-n A C h R$ protein levels after the surgical manipulations. Qualitative changes in $\alpha 7$-nAChR levels were detected by histochemical staining of frozen ganglionic sections using $\alpha$-Bgt that specifically binds to $\alpha 7$ subunits in chick CG neurons and HRP for visualization (Jacob and Berg, 1983; Smith et al., 1985; Conroy and Berg, 1995). The $\alpha 7-\mathrm{nAChR}$ staining is primarily intracellular and associated with organelles that function in the synthesis, processing, and transport of integral plasma membrane proteins (Carbonetto and Fambrough, 1979; Jacob et al., 1986). In comparison, surface $\alpha 7-\mathrm{nAChRs}$ are not readily detected in the thin cryostat sections.

In neurons deprived of synaptic partners, less intense $\alpha 7$ - 


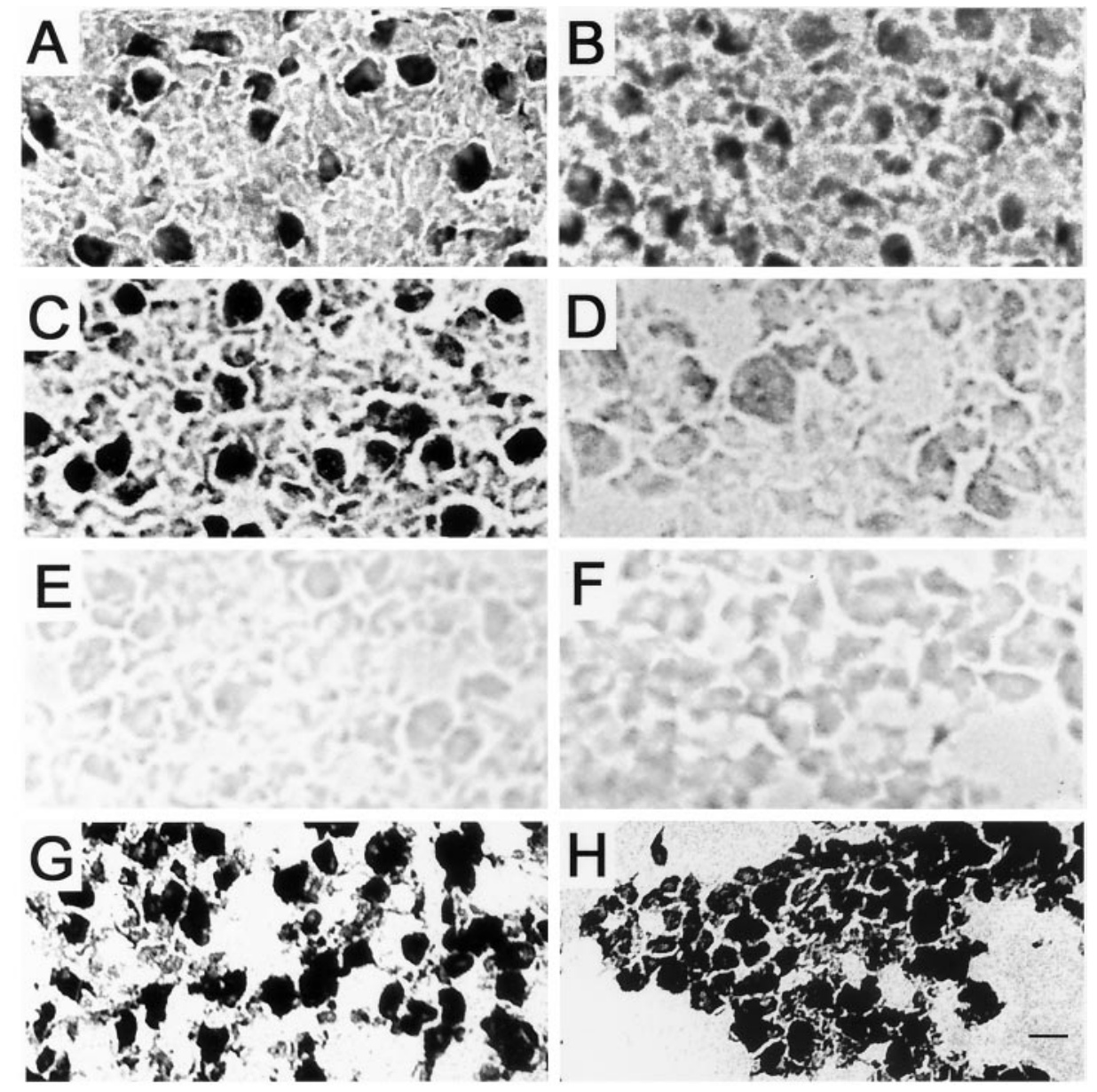

Figure 3. $\alpha 7-\mathrm{nAChR}$ staining is specifically reduced in $\mathrm{CG}$ neurons deprived of synaptic partners compared with control neurons. Cryostat sections of CGs from operated and control embryos at E12-E14 were incubated with biotinylated $\alpha$-Bgt followed by streptavidinHRP. The sections were then reacted for peroxidase activity and examined by bright-field microscopy. $A$, Sham-operated E14 CG; $B$, input-deprived $\mathrm{E} 14 \mathrm{CG}$; $C$, contralateral control E12 CG; $D$, target tissue-deprived E12 $\mathrm{CG} ; E$, staining control E14 CG; $F$, both inputand target-deprived E12 CG. Most of the neuronal somata are intensely stained in the unoperated control ganglion sections $(A, C)$. The interiors of the somata are filled with HRP reaction product deposits, with the exception of the nuclei, which, when visible, are not stained above background levels $(E)$. In contrast, the majority of the neuronal somata are moderately stained in the input-deprived ganglion section $(B)$, only lightly stained in the target-deprived ganglion section $(D)$, and just slightly stained above background levels in the input- and target-deprived ganglion section $(F)$. Specific $\alpha$-Bgt staining is demonstrated by the absence of HRP reaction product in the sham-operated E14 ganglion section that was incubated with PBS in place of biotinylated $\alpha$-Bgt $(C)$. In contrast to the declines in $\alpha 7$ nAChRs, similar relative levels of MAP2 immunolabeling are present in the input- and target-deprived E8 ganglion section $(H)$ and the sham-operated E8 ganglion section $(G)$. Intense MAP2 immunoperoxidase labeling fills the soma and dendrites of the developing CG neurons in $G$ and $H$. The decreases in $\alpha 7$-nAChR levels are specific. Scale bar: $A-F$, $30 \mu \mathrm{m} ; G, H, 35 \mu \mathrm{m}$.
$\mathrm{nAChR}$ staining is present in the somata relative to age-matched control neurons, suggesting a decline in the number of $\alpha 7$ nAChRs in the internal biosynthetic pool (Fig. 3). Compared with the declines in input-deprived neurons (Fig. 3B), greater decreases in $\alpha 7$-nAChR protein levels are seen in the absence of target tissues (Fig. 3D). The lowest $\alpha 7$-nAChR levels are present in neurons deprived of both inputs and targets (Fig. $3 F$ ). The declines are specific: there are no detectable differences in the relative levels of soma immunoreactivity for three other neuronspecific components, the synaptic vesicle protein SV2 and two microtubule-associated proteins MAP1B and MAP2 in synaptic partner-deprived CG neurons compared with control neurons (Fig. 3G,H) (Arenella et al., 1993). In summary, the histochemical staining data demonstrate qualitative reductions in $\alpha 7$ nAChR protein levels that resemble the quantitative changes in $\alpha 7$ mRNA levels in CG neurons from operated embryos. The correlation suggests that the regulation of $\alpha 7-\mathrm{nAChR}$ expression may occur at the level of gene transcription.

\section{Reduced activity specifically lowers $\alpha 7-n A C h R$, but not $\alpha 3-n A C h R$, levels}

To identify the regulatory signals provided by synaptic partners, we examined the effects of activity on $\alpha 7$-nAChR protein levels in CGs neurons of newly hatched chicks. We used visual deprivation to greatly reduce activity in the retinal input pathway to the $C G$ without directly damaging the intercellular connections (Shih et al., 1993: Pendrak et al., 1995). Visual deprivation was achieved by either dark rearing of chicks immediately after hatching in a darkened incubator or application of a light-tight occluder over one eye, with the contralateral uncovered eye serving as an internal control. These approaches prevent light entry and greatly reduce activity in the retina that drives the central visual pathway that innervates the CG neurons (Gamlin et al., 1982, 1984; Gamlin and Reiner, 1991). Previous reports show that visual deprivation (monocular occlusion or lid suture) significantly reduces by $28 \%$ the activity of choline acetyltransferase (ChAT), the acetylcholine biosynthetic enzyme, in the CG (Pendrak et al., 1995).

Visual deprivation decreases the total number of $\alpha 7$-nAChRs per ganglion as detected by specific ${ }^{125} \mathrm{I}-\alpha \mathrm{Bgt}$ binding in ganglionic detergent extracts and normalizing for protein. Dark rearing for 1 week reduces $\alpha 7-\mathrm{nAChR}$ levels per ganglion to $75 \%$ of control diurnally reared chick CG values $(p<0.05$; Student's $t$ test) (Fig. 4). No additional decline is observed at 2 weeks of dark rearing. Similarly, light-tight patching one eye for 1 week reduces $\alpha 7$-nAChRs to $85 \%$ of the contralateral control CG value, a small but significant decrease ( $p<0.025$; Student's paired $t$ test) (Fig. 4). Compared with dark rearing, monocular occlusion is less effective at reducing activity because there are some bilateral afferent projections in the central visual pathway to the CG (Gamlin et al., 1982; Gamlin and Reiner, 1991). As a negative control, covering the eye with a clear occluder for 1 week, which permits light entry and visual function, has no significant effect on $\alpha 7$-nAChR levels (Fig. 4). The declines in $\alpha 7$-nAChRs observed after visual deprivation represent reductions in the number of receptors rather than decreases in the affinity of receptor for the toxin probe as determined by increasing the concentration of ${ }^{125} \mathrm{I}-\alpha \mathrm{Bgt}$ threefold in the standard binding assay (data not 


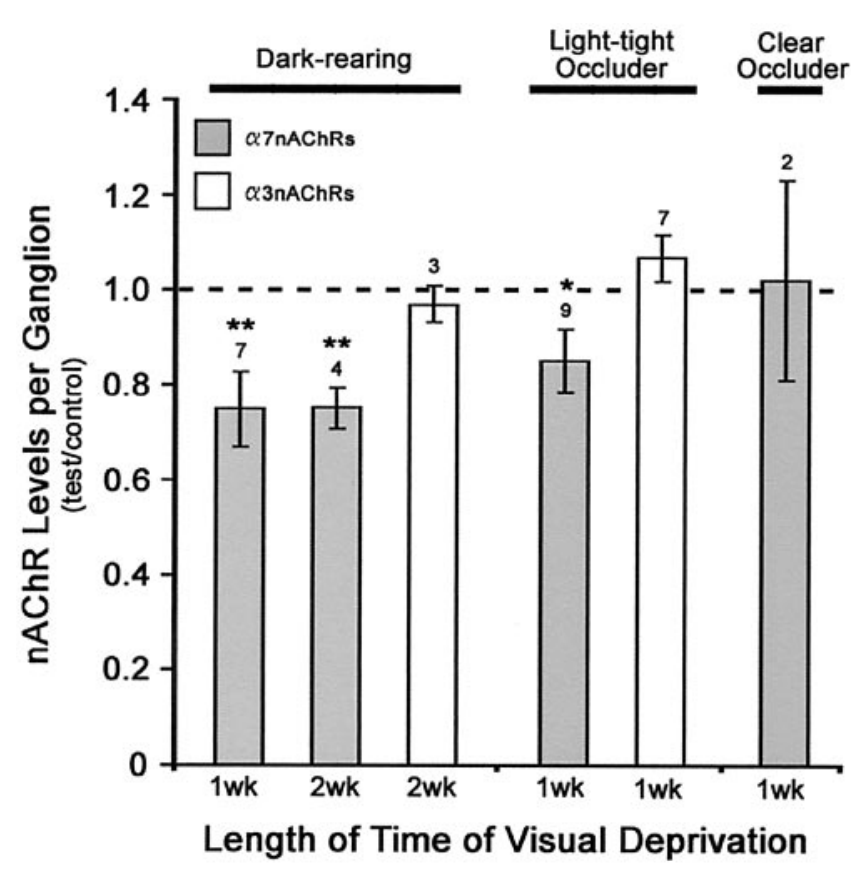

Figure 4. Visual deprivation downregulates $\alpha 7$-nAChR levels, but not $\alpha 3$-nAChRs, in newly hatched chick CG neurons. Visual deprivation was used to reduce activity in retinal inputs to CG neurons. Chicks were either dark reared immediately after hatching, or a light-tight occluder was applied over one eye, with the contralateral uncovered eye serving as an internal control. Dark-reared chick CGs are compared with diurnally reared chick CGs at matched ages. To control for nonspecific effects of covering the eye with a plastic goggle, a clear occluder was applied on separate chicks. The total number of $\alpha 7$-nAChRs per ganglion was determined by the specific binding of ${ }^{125} \mathrm{I}-\alpha$-Bgt in ganglionic detergent extracts. Results represent the mean \pm SEM of the specific activity (the number of binding sites per ganglionic protein) of the test, with both the mean and SEM values normalized to the mean of the appropriate control. The number of separate determinations is indicated above each bar. The hatched line represents the control diurnally reared chick CG value. For comparison with $\alpha 7$-nAChRs, the total number of $\alpha 3$-nAChRs was assayed in separate ganglia using ${ }^{125} \mathrm{I}-\mathrm{mAb}-35 . \alpha 7-\mathrm{nAChR}$ levels are reduced in visually deprived chick CGs, whereas $\alpha 3$-nAChR levels are not. Asterisks indicate statistically significant differences in the raw data of Bgt-specific activities in test versus control CGs based on the Student's $t$ test for dark-reared chicks and the Student's paired $t$ test for monocular occluded chicks; ${ }^{* *} p<0.05$ and ${ }^{*} p<0.025$, respectively.

shown). In all of these experiments, the number of $\alpha 7$-nAChRs was calculated assuming, for convenience, a 1:1 stoichiometry of $\alpha$-Bgt bound to receptor. The number of $\alpha$-Bgt binding sites per receptor is not known (Chen and Patrick, 1997; Rangwala et al., 1997). However, the exact stoichiometry is not important for the present studies, which depend only on a comparison of the relative amounts of $\alpha 7$-nAChRs.

In contrast to the declines in $\alpha 7$-nAChRs seen with visual deprivation, $\alpha 3$-nAChR levels are not altered. Neither dark rearing nor monocular occlusion produce a significant change in the total number of $\alpha 3$-nAChRs per ganglion as detected by specific ${ }^{125} \mathrm{I}-\mathrm{mAb}-35$ binding in ganglionic detergent extracts and normalizing for protein (Fig. 4). These unexpected results suggest that reduced activity regulates the levels of extrasynaptic $\alpha 7-\mathrm{nAChRs}$ but has no effect on synaptic $\alpha 3$-nAChR levels, in CG neurons in situ.

\section{DISCUSSION}

Two major findings are reported here. One, although $\alpha 7$-nAChRs are excluded from the synapse, their developmental expression is regulated by innervation and target tissue interactions in embryonic chick CG neurons in situ. Two, reduced activity downregulates perisynaptic $\alpha 7$-nAChR levels but not synaptic $\alpha 3$-nAChRs. Innervation and target tissue interactions both induce increases in $\alpha 7$ transcript and protein levels during synapse formation in the $\mathrm{CG}$, with retrograde signals from the target tissues having the greater inductive effect. The absence of synaptic partners causes changes in perisynaptic $\alpha 7-\mathrm{nAChR}$ expression that primarily parallel that seen for synaptic $\alpha 3$-nAChRs (Table 1). However, there are some differences in their regulation. Most striking, reduced activity has unique effects on $\alpha 7-\mathrm{nAChR}$ levels. These results establish a difference in the signals that mediate the regulatory effects of synaptic partners on the two nicotinic receptor types. The parallel expression of $\alpha 7-\mathrm{nAChRs}$ and $\alpha 3-$ nAChRs, mediated at least in part by different regulatory signals, suggests that perisynaptic $\alpha 7$-nAChRs are likely to have important and distinct synapse-related functions in vertebrate autonomic neurons.

The present study establishes the parallel regulation of the subunits of perisynaptic $\alpha 7$-nAChRs and synaptic $\alpha 3$-nAChRs, with one exception. Innervation induces increases in $\alpha 7$ mRNA that closely resemble in time course and extent those seen for all of the $\alpha 3$-nAChR subunit mRNAs, $\alpha 3, \beta 4$, and $\alpha 5$, suggesting that innervation coordinately regulates the developmental expression of perisynaptic and synaptic nAChRs (this study; Levey et al., 1995). In contrast, the target tissues have some differential regulatory effects. $\alpha 7$ mRNA levels are upregulated in a manner resembling $\alpha 3$ and $\beta 4$, whereas $\alpha 5$ mRNA is not affected by target tissue interactions in embryonic CG neurons (this study; Levey et al., 1995). The parallel regulation of perisynaptic $\alpha 7$ and synaptic $\alpha 3$ and $\beta 4$, but not $\alpha 5$, is interesting. For $\alpha 3$-nAChR complexes, $\alpha 3$ is the essential subunit, being required for surface expression of functional $\alpha 3-\mathrm{nAChRs}$ and their targeting to the synapse (De Koninck and Cooper, 1995; Levey et al., 1995; Williams et al., 1998; Xu et al., 1999a). The $\beta 4$ subunit is required for $\alpha 3$-nAChR complex assembly (Xu et al., 1999b). In contrast, $\alpha 5$ is needed for the formation of high-conductance $\alpha 3$-nAChR channels and appears to be a developmentally late component of the $\alpha 3-\mathrm{nAChR}$ complex in CG neurons (Margiotta and Gurantz, 1989; Levey et al., 1995; Ramirez-Latorre et al., 1996; Wang et al., 1996). For perisynaptic $\alpha 7$-nAChRs, $\alpha 7$ is the critical ligand-binding subunit, and, in many neural tissues, $\alpha 7$-nAChRs are homopentamers (Chen and Patrick, 1997; Drisdel and Green, 2000). In summary, our results show that the transcript levels of $\alpha 7$ and $\alpha 3$, the key subunits of the perisynaptic and synaptic nAChR complexes, respectively, are regulated in parallel during synapse formation in chick CG neurons.

At mature ages, perisynaptic $\alpha 7$-nAChR expression continues to be regulated by innervation and target tissue interactions. In newly hatched chickens, the disruption of functional synaptic connections (preganglionic denervation or postganglionic axotomy) causes specific declines in $\alpha 7$-nAChR protein levels (Jacob and Berg, 1987; Zhou et al., 2001). Again, perisynaptic $\alpha 7$ $\mathrm{nAChR}$ and synaptic $\alpha 3$-nAChR levels are regulated similarly at these later ages but, in this case, with distinct time courses. After denervation and axotomy, the decreases in $\alpha 7$-nAChRs are steeper and more rapid than those seen for $\alpha 3$-nAChRs (Jacob and Berg, 1987). Altogether, this study and our previous work demonstrate that signals from both presynaptic inputs and target tissues are required for the initial induction and the maintenance of mature levels of $\alpha 7-\mathrm{nAChR}$ expression in $\mathrm{CG}$ neurons in situ.

The regulatory signals that mediate the effects of innervation 
and target tissues on $\alpha 7$-nAChR expression are as yet primarily undefined. We focused on the role of electrical activity as a potential regulatory signal. Precedence demonstrates that electrical activity regulates neural expression of other neurotransmitter receptor types (Philpot et al., 2001; Kilman et al., 2002). We used visual deprivation to greatly reduce activity in the retinal inputs to the CG neurons via multisynaptic central visual pathways (Gamlin et al., 1982, 1984; Gamlin and Reiner, 1991). Precedence shows that visual deprivation significantly reduces the levels of particular synapse-related proteins in the CG. Specifically, the activity of ChAT, the acetylcholine biosynthetic enzyme, is reduced by $28 \%$ (Pendrak et al., 1995). We show here that visual deprivation selectively regulates perisynaptic $\alpha 7-n A C h R$ levels, but not synaptic $\alpha 3-n A C h R s$, in CG neurons of newly hatched chicks. Similar to these in vivo effects of visual deprivation, in vitro studies show that activity (membrane depolarization) specifically influences $\alpha 7$, but not $\alpha 3$, nAChR transcript and protein levels in neonatal rat sympathetic neurons (De Koninck and Cooper, 1995). $\alpha 7$-nAChR levels in the rodent somatosensory cortex are also regulated by sensory deprivation, the removal of all vibrissa on one side of the face (Bina et al., 1998). In the chick CG, the declines in $\alpha 7$-nAChR protein levels caused by visual deprivation in vivo are modest (1.3-fold) but significant. In comparison, there are greater declines in $\alpha 7$-nAChR protein levels (twofold) after the disruption of functional connections (preganglionic denervation) in newly hatched chick CGs (Jacob and Berg, 1987). It should be noted that visual deprivation is likely to reduce, but not eliminate, synaptic activation of CG neurons (Jackson, 1983). The effects of reduced activity may be direct or indirect, possibly involving other regulatory signals (Loeb et al., 2002). Thus, factors other than activity may mediate the regulatory effects of visual deprivation on $\alpha 7$-nAChR levels. Intercellular signals, such as specific factors, influence $\alpha 7$-nAChR levels in neurons. Neuregulin (the neural-specific cysteine-rich domain-containing isoform) is a presynaptic input-derived soluble factor that increases $\alpha 7$-nAChR levels in sympathetic neurons in vitro (Yang et al., 1998; Liu et al., 2001). Neuregulin splice variants are expressed in presynaptic inputs to the CG (Corfas et al., 1995). They are also likely expressed in CG neurons, suggesting the possible contribution of autocrine and paracrine actions of this soluble factor (Corfas et al., 1995; Sandrock et al., 1995). In addition, two distinct target tissue-derived factors have been isolated that influence $\alpha 7$-nAChR levels in opposite ways (Nishi, 1994; Finn and Nishi, 1996). Ciliary neurotrophic factor, a trophic factor, specifically downregulates $\alpha 7$-nAChRs, whereas a soluble component of $50 \mathrm{kDa}$ increases $\alpha 7$ levels in CG neurons in vitro (Halvorsen and Berg, 1989; Halvorsen et al., 1991). In the present study, we show additive effects of inputs and target tissues on $\alpha 7-\mathrm{nAChR}$ levels, suggesting that the two different synaptic partners may provide distinct regulatory signals. Overall, the combinatorial regulatory effects of activity and multiple factors are likely to govern $\alpha 7$ subunit levels during synapse formation and maturation in chick autonomic neurons in situ.

Our findings that innervation and target tissue interactions induce increases in $\alpha 7$-nAChR expression during synapse differentiation suggest that the perisynaptic receptors may have synapse-related functions. Recent electrophysiological studies show that $\alpha 7-\mathrm{nAChR}$ activation is required for reliable synaptic transmission in the early embryonic chick CG (Chang and Berg, 1999). Greater activity may stabilize the newly formed synaptic connections, resulting in the uptake of essential trophic factors and survival of the neurons during the critical developmental period of synapse formation and elimination (Meriney et al., 1987: Maderdrut et al., 1988; Pugh and Margiotta, 2000). However, during synapse maturation at older embryonic ages, $\alpha 7$ $\mathrm{nAChR}$ activation is no longer required for reliable synaptic transmission (Chang and Berg, 1999). Other synapse-related functions are likely as suggested by the $\alpha 7-n A C h R$ abundant surface expression, spatial segregation, and distinct functional properties relative to $\alpha 3-\mathrm{nAChRs}$ on $\mathrm{CG}$ neurons. In particular, $\alpha 7$-nAChRs have a higher $\mathrm{Ca}^{2+}$ permeability and faster kinetics of activation and desensitization (Zhang et al., 1996; Ullian et al., 1997). Our findings that visual deprivation causes declines in $\alpha 7$-nAChRs, but not $\alpha 3$-nAChRs, suggest that $\alpha 3$-nAChRs are required to maintain synaptic transmission, whereas $\alpha 7-\mathrm{nAChRs}$ are activity sensors in the postsynaptic neuron. A recent report demonstrates that nicotinic signaling to $\mathrm{CG}$ neurons can induce $\mathrm{Ca}^{2+}$-dependent plasticity changes (prolonged activation of phosphorylated cAMP response element-binding protein and gene expression) under certain conditions (Chang and Berg, 2001). Activation of $\mathrm{nAChRs}$ is required, whereas voltage-gated $\mathrm{Ca}^{2+}$ channels are silent, with intracellular $\mathrm{Ca}^{2+}$ levels being the critical determinant. In particular, the amounts and the temporal and spatial patterns of internal $\mathrm{Ca}^{2+}$ elevations are important. Activity-dependent changes in $\alpha 7-\mathrm{nAChR}$ levels are likely to affect the critical variable of $\mathrm{Ca}^{2+}$ influx in $\mathrm{CG}$ neurons. We propose that $\alpha 7-n A C h R s$ have the unique function of activity sensors in CG neurons. The activity-dependent regulation of extrasynaptic $\alpha 7-n A C h R s$ may be an important mechanism for CG neurons to detect alterations in presynaptic activity levels and respond by $\mathrm{Ca}^{2+}$-dependent plasticity changes in gene expression.

In summary, our data demonstrate that, within single $\mathrm{CG}$ neurons, the coexpression of extrasynaptic $\alpha 7$-nAChRs and synaptic $\alpha 3-n A C h R s$ is induced by innervation and target tissue interactions, with some differences in the underlying regulatory signals. The coexpression of the two nicotinic receptor subtypes is important for optimal synaptic signaling and plasticity in neural circuits of the vertebrate autonomic nervous system.

\section{REFERENCES}

Abercrombie M (1946) Estimation of nuclear population from microtome sections. Anat Rec 94:239-247.

Arenella LS, Oliva JM, Jacob MH (1993) Reduced levels of acetylcholine receptor expression in chick ciliary ganglion neurons developing in the absence of innervation. J Neurosci 13:4525-4537.

Bina KG, Park M, O’Dowd DK (1998) Regulation of $\alpha 7$ nicotinic acetylcholine receptors in mouse somatosensory cortex following whisker removal at birth. J Comp Neurol 397:1-9.

Broide RS, Robertson RT, Leslie FM (1996) Regulation of alpha7 nicotinic acetylcholine receptors in the developing rat somatosensory cortex by thalamocortical afferents. J Neurosci 16:2956-2971

Carbonetto S, Fambrough DM (1979) Synthesis, insertion into the plasma membrane, and turnover of alpha-bungarotoxin receptors in chick sympathetic neurons. J Cell Biol 81:555-569.

Chang KT, Berg DK (1999) Nicotinic acetylcholine receptors containing alpha7 subunits are required for reliable synaptic transmission in situ. J Neurosci 19:3701-3710.

Chang KT, Berg DK (2001) Voltage-gated channels block nicotinic regulation of CREB phosphorylation and gene expression in neurons. Neuron 32:855-865.

Chen D, Patrick JW (1997) The alpha-bungarotoxin-binding nicotinic acetylcholine receptor from rat brain contains only the alpha7 subunit. Biol Chem 272:24024-24029.

Conroy WG, Berg DK (1995) Neurons can maintain multiple classes of nicotinic acetylcholine receptors distinguished by different subunit compositions. J Biol Chem 270:4424-4431.

Corfas G, Rosen KM, Aratake H, Krauss R, Fischbach GD (1995) Differential expression of ARIA isoforms in the rat brain. Neuron 14:103-115.

Corriveau RA, Berg DK (1993) Coexpression of multiple acetylcholine 
receptor genes in neurons: quantification of transcripts during development. J Neurosci 13:2662-2671.

Couturier S, Bertrand D, Matter J-M, Hernandez M-C, Bertrand S, Millar N, Valera S, Barkas T, Ballivet M (1990) A neuronal nicotinic acetylcholine receptor subunit $(\alpha 7)$ is developmentally regulated and forms a homo-oligomeric channel blocked by $\alpha$-Btx. Neuron 5:847-856.

De Koninck P, Cooper E (1995) Differential regulation of neuronal nicotinic $\mathrm{ACh}$ receptor subunit genes in cultured neonatal rat sympathetic neurons: specific induction of $\alpha 7$ by membrane depolarization through a $\mathrm{Ca}^{2+} /$ calmodulin-dependent kinase pathway. J Neurosci 15:7966-7978.

Devay P, McGehee DS, Yu CR, Role LW (1999) Target-specific control of nicotinic receptor expression at developing interneuronal synapses in chick. Nat Neurosci 2:528-534.

Dourado MM, Brumwell C, Wisgirda ME, Jacob MH, Dryer SE (1994) Target tissues and innervation regulate the characteristics of $\mathrm{K}^{+}$currents in chick ciliary ganglion neurons developing in situ. J Neurosci $14: 3156-3165$

Drisdel RC, Green WN (2000) Neuronal $\alpha$-bungarotoxin receptors are $\alpha 7$ subunit homomers. J Neurosci 20:133-139.

Engisch KL, Fischbach GD (1990) The development of ACH- and GABA-activated currents in normal and target-deprived embryonic chick ciliary ganglia. Dev Biol 139:417-426.

Engisch KL, Fischbach GD (1992) The development of ACh- and GABA-activated currents in embryonic chick ciliary ganglion neurons in the absence of innervation in vivo. J Neurosci 12:1115-1125.

Feramisco JR, Smart JE, Burridge K, Helfman DM, Thomas GP (1982) Co-existence of vinculin and a vinculin-like protein of higher molecular weight in smooth muscle. J Biol Chem 257:11024-11031.

Finn TP, Nishi R (1996) Expression of a chicken ciliary neurotrophic factor in targets of ciliary ganglion neurons during and after the cell-death phase. J Comp Neurol 366:559-571.

Furber S, Oppenheim RW, Prevette D (1987) Naturally occurring neuron death in the ciliary ganglion of the chick embryo following removal of preganglionic input: evidence for the role of afferents in ganglion cell survival. J Neurosci 7:1816-1832.

Gamlin PD, Reiner A (1991) The Edinger-Westphal nucleus: sources of input influencing accommodation, pupilloconstriction, and choroidal blood flow. J Comp Neurol 306:425-438.

Gamlin PD, Reiner A, Karten H (1982) Substance P-containing neurons of the avian suprachiasmatic nucleus project directly to the nucleus of Edinger-Westphal. Proc Natl Acad Sci USA 79:3891-3895.

Gamlin PD, Reiner A, Erichsen JT, Karten HJ, Cohen DH (1984) The neural substrate for the pupillary light reflex in the pigeon (Columba livia). J Comp Neurol 226:523-543.

Gottlieb MD, Fugate-Wentzek LA, Wallman J (1987) Different visual deprivations produce different ametropias and different eye shapes. Invest Ophthalmol Vis Sci 28:1225-1235.

Halvorsen SW, Berg DK (1989) Specific down-regulation of the $\alpha$-bungarotoxin binding component on chick autonomic neurons by ciliary neuronotrophic factor. J Neurosci 9:3673-3680.

Halvorsen SW, Schmid HA, McEachern AE, Berg DK (1991) Regulation of acetylcholine receptors on chick ciliary ganglion neurons by components from the synaptic target tissue. J Neurosci 11:2177-2186.

Hamburger V, Hamilton HL (1951) A series of normal stages in the development of the chick embryo. J Morphol 88:49-82.

Higuchi R, Krummel B, Saiki RK (1988) A general method of in vitro preparation and specific mutagenesis of DNA fragments: study of protein and DNA interactions. Nucleic Acids Res 16:7351-7367.

Horch HL, Sargent PB (1995) Perisynaptic surface distribution of multiple classes of nicotinic acetylcholine receptors on neurons in the chicken ciliary ganglion. J Neurosci 15:7778-7795.

Ikonomov OC, Kulesa MC, Shisheva AC, Jacob MH (1998) Innervation and target tissue interactions induce Rab-GDP dissociation inhibitor (GDI) expression during peripheral synapse formation in developing chick ciliary ganglion neurons in situ. J Neurosci 18:6331-6339.

Jackson PC (1983) Reduced activity during development delays the normal rearrangement of synapses in the rabbit ciliary ganglion. J Physiol (Lond) 345:319-327.

Jacob MH (1991) Acetylcholine receptor expression in developing chick ciliary ganglion neurons. J Neurosci 11:1701-1712

Jacob MH, Berg DK (1983) The ultrastructural localization of $\alpha$-bungarotoxin binding sites in relation to synapses on chick ciliary ganglion neurons. J Neurosci 3:260-271.

Jacob MH, Berg DK (1987) Effects of preganglionic denervation and postganglionic axotomy on acetylcholine receptors in the chick ciliary ganglion. J Cell Biol 105:1847-1854.

Jacob MH, Lindstrom JM, Berg DK (1986) Surface and intracellular distribution of a putative neuronal nicotinic acetylcholine receptor. J Cell Biol 103:205-214.

Kilman V, van Rossum MC, Turrigiano GG (2002) Activity deprivation reduces miniature IPSC amplitude by decreasing the number of postsynaptic $\mathrm{GABA}_{\mathrm{A}}$ receptors clustered at neocortical synapses. J Neurosci 22:1328-1337.
Landmesser L, Pilar G (1972) The onset and development of transmission in the chick ciliary ganglion. J Physiol (Lond) 222:691-713.

Landmesser L, Pilar G (1974) Synaptic transmission and cell death during normal ganglionic development. J Physiol (Lond) 241:737-749.

Lee MK, Tuttle JB, Rebhun LI, Cleveland DW, Frankfurter A (1990) The expression and posttranslational modification of a neuron-specific beta-tubulin isotype during chick embryogenesis. Cell Motil Cytoskeleton $17: 118-132$.

Levey MS, Jacob MH (1996) Changes in the regulatory effects of cellcell interactions on neuronal AChR subunit transcript levels after synapse formation. J Neurosci 16:6878-6885.

Levey MS, Brumwell CL, Dryer SE, Jacob MH (1995) Innervation and target tissue interactions differentially regulate acetylcholine receptor subunit mRNA levels in developing neurons in situ. Neuron $14: 153-162$.

Liu Y, Ford B, Mann MA, Fischbach GD (2001) Neuregulins increase $\alpha 7$ nicotinic acetylcholine receptors and enhance excitatory synaptic transmission in GABAergic interneurons of the hippocampus. J Neurosci 21:5660-5669.

Loeb JA, Hmadcha A, Fischbach GD, Land SJ, Zakarian VL (2002) Neuregulin expression at neuromuscular synapses is modulated by synaptic activity and neurotrophic factors. J Neurosci 22:2206-2214.

Loring RH, Zigmond RE (1987) Ultrastructural distribution of ${ }^{125} \mathrm{I}$ toxin $\mathrm{F}$ binding sites on chick ciliary neurons: synaptic localization of a toxin that blocks ganglionic nicotinic receptors. $\mathrm{J}$ Neurosci 7:2153-2162.

Loring RH, Dahm LM, Zigmond RE (1985) Localization of alphabungarotoxin binding sites in the ciliary ganglion of the embryonic chick: an autoradiographic study at the light and electron microscopic level. Neuroscience 14:645-660.

Maderdrut JL, Oppenheim RW, Prevette D (1988) Enhancement of naturally occurring cell death in the sympathetic and parasympathetic ganglia of the chicken embryo following blockade of ganglionic transmission. Brain Res 444:189-194.

Margiotta JF, Gurantz D (1989) Changes in the number, function, and regulation of nicotinic acetylcholine receptors during neuronal development. Dev Biol 135:326-339.

Meriney SD, Pilar G (1987) Cholinergic innervation of the smooth muscle cells in the choroid coat of the chick eye and its development. J Neurosci 7:3827-3839.

Meriney SD, Pilar G, Ogawa M, Nunez R (1987) Differential neuronal survival in the avian ciliary ganglion after chronic acetylcholine receptor blockade. J Neurosci 7:3840-3849.

Nishi R (1994) Target-derived molecules that influence the development of neurons in the avian ciliary ganglion. J Neurobiol 25:612-619.

Pendrak K, Lin T, Stone RA (1995) Ciliary ganglion choline acetyltransferase activity in avian macrophthalmos. Exp Eye Res 60:237-243

Philpot BD, Sekhar AK, Shouval HZ, Bear MF (2001) Visual experience and deprivation bidirectionally modify the composition and function of NMDA receptors in visual cortex. Neuron 29:157-169.

Pilar G, Nunez R, McLennan IS, Meriney SD (1987) Muscarinic and nicotinic synaptic activation of the developing chicken iris. J Neurosci 7:3813-3826

Pugh PC, Berg DK (1994) Neuronal acetylcholine receptors that bind $\alpha$-bungarotoxin mediate neurite retraction in a calcium-dependent manner. J Neurosci 14:889-896.

Pugh PC, Margiotta JF (2000) Nicotinic acetylcholine receptor agonists promote survival and reduce apoptosis of chick ciliary ganglion neurons. Mol Cell Neurosci 15:113-122.

Ramirez-Latorre J, Yu CR, Qu X, Perin F, Karlin A, Role L (1996) Functional contributions of alpha5 subunit to neuronal acetylcholine receptor channels. Nature 380:347-351.

Rangwala F, Drisdel RC, Rakhilin S, Ko E, Atluri P, Harkins AB, Fox AP, Salman SS, Green WN (1997) Neuronal alpha-bungarotoxin receptors differ structurally from other nicotinic acetylcholine receptors. J Neurosci 17:8201-8212.

Sandrock Jr AW, Goodearl AD, Yin QW, Chang D, Fischbach GD (1995) ARIA is concentrated in nerve terminals at neuromuscular junctions and at other synapses. J Neurosci 15:6124-6136.

Shih YF, Fitzgerald ME, Norton TT, Gamlin PD, Hodos W, Reiner A (1993) Reduction in choroidal blood flow occurs in chicks wearing goggles that induce eye growth toward myopia. Curr Eye Res 12:219-227.

Shoop RD, Martone ME, Yamada N, Ellisman MH, Berg DK (1999) Neuronal acetylcholine receptors with $\alpha-7$ subunits are concentrated on somatic spines for synaptic signaling in embryonic chick ciliary ganglia. J Neurosci 19:692-704.

Smith MA, Stollberg J, Lindstrom JM, Berg DK (1985) Characterization of a component in chick ciliary ganglia that cross-reacts with monoclonal antibodies to muscle and electric organ acetylcholine receptor. J Neurosci 5:2726-2731.

Sullivan KF, Havercroft JC, Machlin PS, Cleveland DW (1986) Sequence and expression of the chicken beta 5- and beta 4-tubulin genes define a pair of divergent beta-tubulins with complementary patterns of expression. Mol Cell Biol 6:4409-4418. 
Ullian EM, McIntosh JM, Sargent PB (1997) Rapid synaptic transmission in the avian ciliary ganglion is mediated by two distinct classes of nicotinic receptors. J Neurosci 17:7210-7219.

Vernallis AB, Conroy WG, Berg DK (1993) Neurons assemble acetylcholine receptors with as many as three kinds of subunits while maintaining subunit segregation among receptor subtypes. Neuron 10:451-464.

Wallman J, Ledoux C, Friedman MB (1978) Simple devices for restricting the visual fields of birds. Behav Res Methods Instrum 10:401-403.

Wang F, Gerzanich V, Wells GB, Anand R, Peng X, Keyser K, Lindstrom J (1996) Assembly of human neuronal nicotinic receptor alpha5 subunits with alpha3, beta2, and beta4 subunits. J Biol Chem 271:17656-17665.

Williams BM, Temburni MK, Levey MS, Bertrand S, Bertrand D, Jacob MH (1998) The long internal loop of the $\alpha 3$ subunit targets nAChRs to subdomains within individual synapses in vivo. Nat Neurosci 1:557-562.

Xu W, Gelber S, Orr-Urtreger A, Armstrong D, Lewis RA, Ou C, Patrick J, Role L, de Biasi M, Beaudet AM (1999a) Megacystis, mydriasis and ion channel deficits in mice lacking the $\alpha 3$ neuronal nicotinic acetyl choline receptor. Proc Natl Acad Sci USA 96:5746-5751.

Xu W, Orr-Urtreger A, Nigro F, Gelber S, Sutcliffe CB, Armstrong D, Patrick JW, Role LW, Beaudet AL, De Biasi M (1999b) Multiorgan autonomic dysfunction in mice lacking the $\beta 2$ and the $\beta 4$ subunits of neuronal nicotinic acetylcholine receptors. J Neurosci 19:9298-9305.

Yang X, Kuo Y, Devay P, Yu C, Role L (1998) A cysteine-rich isoform of neuregulin controls the level of expression of neuronal nicotinic receptor channels during synaptogenesis. Neuron 20:255-270.

Zhang ZW, Coggan JS, Berg DK (1996) Synaptic currents generated by neuronal acetylcholine receptors sensitive to alpha-bungarotoxin. Neuron 17:1231-1240.

Zhou Y, Deneris E, Zigmond RE (1998) Differential regulation of levels of nicotinic receptor subunit transcripts in adult sympathetic neurons after axotomy. J Neurobiol 34:164-178.

Zhou Y, Deneris E, Zigmond RE (2001) Nicotinic acetylcholine receptor subunit proteins alpha7 and beta4 decrease in the superior cervical ganglion after axotomy. J Neurobiol 46:178-192. 